\title{
Analyzing the Impact of Simulated Multispectral Images on Water Classification Accuracy by Means of Spectral Characteristics ${ }^{3}$
}

\begin{abstract}
Remote sensing is widely applied in examining the parameters of the state and quality of water. Spectral characteristics of water are strictly connected with the dispersion of electromagnetic radiation by suspended matter and the absorption of radiation by water and chlorophyll $a$ and $b$.

Multispectral sensor ALI has bands within the ranges of electromagnetic radiation: blue and infrared, absent in sensors such as Landsat, SPOT, or Aster. The main goal of the article was to examine the influence of the presence of these bands on water classification accuracy carried out for simulated images ALI, Landsat, Spot, and Aster. The simulation of images was based on the hyperspectral image from a Hyperion sensor. Due to the spectral properties of water, all the operations on the images were carried out for the set of bands in visible and near-infrared (VNIR) spectral range. In the framework of these studies, the impact of removing individual bands or sets of bands on the classification results was tested. Tests were carried out for the area of the water body of the Dobczyce Reservoir. It was observed that the lack of a spectral response in the infrared range of ALI image can reduce the accuracy of a classification by as much as $60 \%$. On the other hand, the lack of blue and red bands in the dataset for the classification decreased the accuracy of water classification by $15 \%$ and $10 \%$, respectively.
\end{abstract}

Keywords: spectral simulation, ALI, Spectral Angle Mapper (SAM), hyperspectral images, multispectral images

Received: 15 November 2019; accepted: 4 December 2019

(C) 2020 Authors. This is an open access publication, which can be used, distributed and reproduced in any medium according to the Creative Commons CC-BY 4.0 License.

1 AGH University of Science and Technology, Faculty of Mining Surveying and Environmental Engineering, Krakow, Poland, email: eglo@agh.edu.pl

ORCID ID: https://orcid.org/0000-0001-7326-1592

2 Gdańsk University of Technology, Gdańsk, Poland, email: krystyna.michalowska@pg.edu.pl ORCID ID: https://orcid.org/0000-0001-7749-3622

3 This paper was prepared within the scope of the research subsidy of the Ministry of Science and Higher Education for AGH UST, no. 16.16.150.545 


\section{Introduction}

Remote sensing multispectral and hyperspectral data are widely applied in studying the parameters of the state and quality of water, both marine and inland [1-6]. While analyzing an example of the spectral curve of water (Fig. 1), several characteristic areas can be distinguished. Their occurrence is connected with the presence of a definite component responsible for the shape of the curve. For short waves in the range 400-500 $\mathrm{nm}$ (area A), low reflection values are caused by the absorption of radiation by chlorophyll a, carotenoids and dissolved organic matter [5]. Maximal reflection values in the range 500-600 nm (area B) occur as a result of poor absorption of the radiation by pigments (e.g., pigments of algae) and the dispersion of radiation caused by the particles of suspended inorganic matter and phytoplankton [6]. Areas " $\mathrm{C}$ " and " $\mathrm{D}$ " (620-650 nm) are connected with the occurrence of absorption peaks of pigments e.g. phycocyanin - a pigment present in Rhodophyta (red algae) and Cyanobacteriae (blue-green algae) [6]. For wavelengths greater than $650 \mathrm{~nm}$ (area E), smaller reflection values can again be observed, which is caused by the presence of chlorophyll and the dispersion of radiation from the walls of particles. The occurrence of a clear peak for wavelengths of about $700 \mathrm{~nm}$ (area F) is a result of the interaction of radiation being dispersed by the suspended matter and absorption of the radiation by water and chlorophyll a [7].

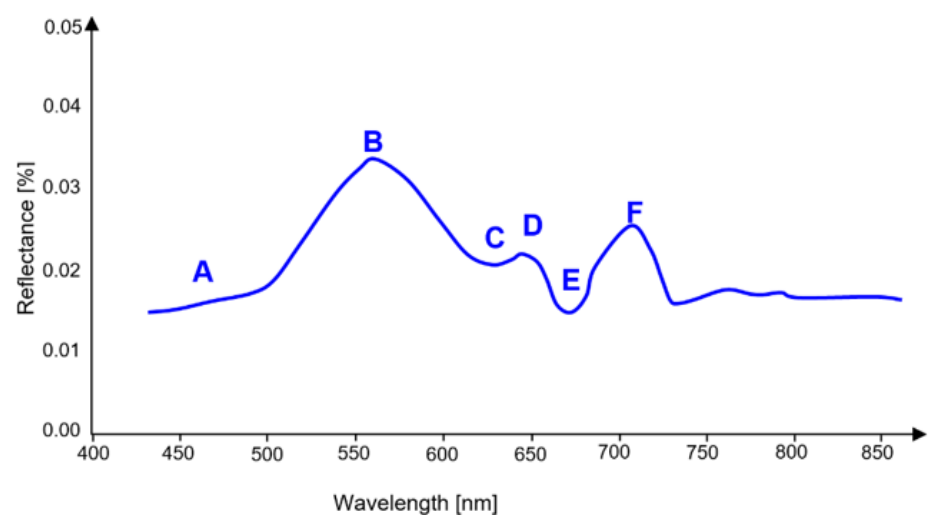

Fig. 1. An example of a spectral curve for inland waters Source: [5]

Simulation of remote sensing data is applied to define their usefulness in various types of applications [6] or at the stage of designing new sensors to test algorithms of data recording and processing [2]. The simulation of remote sensing data is usually carried out as the process of the degradation of spatial resolution/spectral images. To make sure that a simulation provides reliable results, it is necessary to determine the proper parameters such as Spectral Response Function (SRF) [8]. 
SRF is applied in changing the spectral resolution of the set of input data used for the simulation of specific sensors [8-14]. Spectral resampling is a form of the "convolution function" which facilitates the simulation of images characteristic for already functioning sensors, as well as sensors being at the phase of design. If such a function is not known for a given sensor then, assuming that the spectral response has a normal distribution, one can make its approximation with the Gauss function used in the modelling of the spectral answer of individual detectors of the sensor $[15,16]$. The function is represented by the center wavelength and by the width of the spectral range of a given band, which is the function of the full width at half maximum (FWHM). Assuming that the peak of the Gauss function for the center of the spectral range takes the value of 1 , the Gauss function can be expressed by the formula (1) [17]:

$$
g\left(\lambda_{i}, \sigma_{i}\right)=\exp \frac{\left(\lambda_{i}-\lambda\right)^{2}}{2 \sigma^{2}}
$$

where:

$$
\begin{aligned}
& g\left(\lambda_{i}, \sigma_{i}\right) \text { - Gaussian function, } \\
& \lambda_{i}-\text { wavelength, } \\
& \sigma_{i} \text { - bandwidth, or standard deviation: } \\
& \qquad \sigma_{i}=\frac{F W H M}{2 \sqrt{2 \ln 2}}
\end{aligned}
$$

where FWHM - full width at half maximum.

Sensor ALI has bands in the blue and infrared range of electromagnetic radiation, absent in sensors such as Landsat, SPOT, or Aster (Tab. 1). The main objective of the article was to examine the impact of the presence of these bands on the water classification accuracy carried out for simulated images of ALI, Landsat, Spot, and Aster.

\section{Data}

The Hyperion satellite hyperspectral image, recorded on $25^{\text {th }}$ June 2006 within project KBN3T09D 09429, was used for data input [2]. Recording was carried out in 242 bands, i.e., 70 VNIR bands (357-1058 nm) and 172 SWIR (short-wave infrared) bands $(852-2576 \mathrm{~nm})$, with a spectral resolution of about $10 \mathrm{~nm}$. The spectral resolution of the recorded image was $30 \mathrm{~m}$ [18]. The size of the obtained scene was $180 \mathrm{~km} \times 7.7 \mathrm{~km}$. The image was subdued to the procedure of preliminary processing i.e., radiometric correction (removal of noises, so-called stripping and radiometric noise, so-called smilling), atmospheric correction (removal of the influence 
of atmospheric phenomena) [19, 20]. With a properly prepared mask (Fig. 2b), the study area was limited to the largest body of water, found in the processed image (the Dobczyce Reservoir - with an area of $10.7 \mathrm{~km}^{2}$ ) (Fig. 2a, b). This is very important due to the problem of mixed pixels, also known as mixels.

Based on the analysis of the spectral curve of water, for the tests from the processed Hyperion image, 47 bands of VNIR (424.06-892.74 nm) were selected. To classify the image data, reference curves of water were applied (Fig. 2c). They were measured during a spectrometric measurement (in situ) concurrent to the recording of the image [2]. Measurement points are shown in the figure below (Fig. 2a). The localization of the measurement points was strictly connected with the properties of the water and characteristics of the bottom of the reservoir.

a)

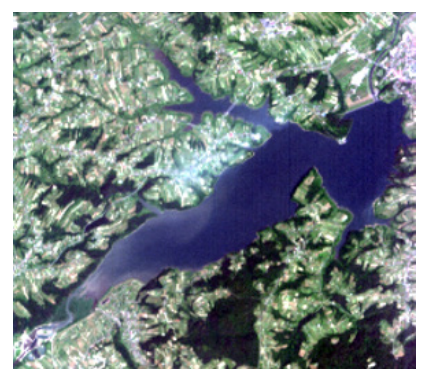

b)

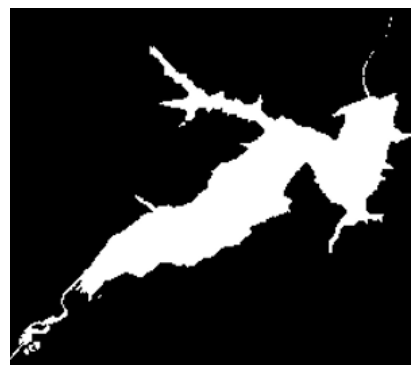

c)

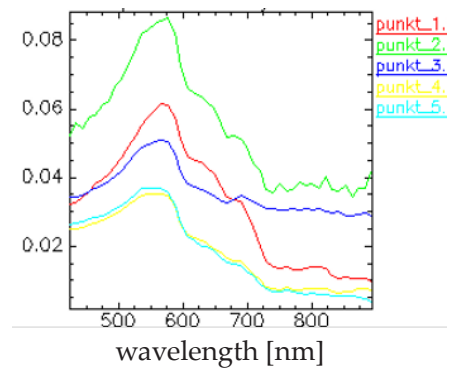

Fig. 2. RGB color composition for the Hyperion image with the marked points of spectrometric measurements (a); mask for the area of the Dobczyce Reservoir (b); spectral curves measured for the waters of the reservoir (c)

\section{Methodology}

Modelling of the spectral responses was carried out with the use of the Gauss model (Formula (1)), using appropriate values of FWHM for each sensor. The values of parameters necessary for spectral resampling procedure i.e., centers of the ranges and real values of FWHM, were obtained from the internet sites of the image suppliers: ALI, Landsat, SPOT, Aster.

The respective images containing SRF were prepared according to the spectral response of subsequent channels of all the analyzed sensors ALI, Landsat, Spot, Aster (Tab. 1). Based on them, spectral resampling of the Hyperion image was carried out. As a result, simulated images were obtained.

To examine the impact of the presence of spectral information from a particular range on the accuracy of the classification of ALI image, images with subsequent bands or sets of eliminated bands were prepared (Tab. 3). At the first stage single bands $1^{\prime}, 1,2,3,4,4^{\prime}$ were subsequently removed. At the second stage, the elimination procedure was applied for six selected sets of bands: $1^{\prime}, 1 ; 1^{\prime}, 4 ; 1^{\prime}, 4^{\prime} ; 1,1^{\prime}, 4$; 
$1,1^{\prime}, 4^{\prime} ; 4,4^{\prime}$. It must be noticed that the elimination of set $1^{\prime}, 4^{\prime}$ produced the image according to the configuration of Landsat (Tab. 1), while the removal of bands $1^{\prime} ; 1,4^{\prime}$ produced the configuration characteristic to the images of Spot and Aster (Tab. 1).

Table 1. Spectral characteristics of the bands of multispectral sensors in VNIR [nm]

\begin{tabular}{|c|c|c|c|c|}
\hline $\begin{array}{c}\text { Number } \\
\text { of bands }\end{array}$ & ALI & Landsat & Spot & Aster \\
\hline \hline $1^{\prime}$ & $433-453$ & - & - & - \\
\hline 1 & $450-515$ & $450-520$ & $500-590$ & $520-600$ \\
\hline 2 & $525-605$ & $520-600$ & $610-680$ & $630-690$ \\
\hline 3 & $630-690$ & $630-690$ & $790-890$ & $780-860$ \\
\hline 4 & $775-805$ & $760-900$ & - & - \\
\hline $4^{\prime}$ & $845-890$ & - & - & - \\
\hline
\end{tabular}

The obtained images were classified with the Spectral Angle Mapper (SAM) method $[2,20]$. To estimate the accuracy of classification, the method of confusion matrix was applied. Based on this method, the Overall Accuracy - OA and kappa coefficient were calculated. As a reference map, the image after SAM classification carried out for the source image from Hyperion was used. Spectral resampling, SAM classification procedure and accuracy estimation were carried out using the ENVI program.

\section{Results}

Table 2 shows the values of the overall accuracy and kappa coefficient obtained for all the simulated images (ALI, Aster, Landsat, Spot) classified with the SAM method. In the classification, only the VNIR bands were taken into account.

Comparing the results of the classification accuracy (Tab. 2) of all simulated images, one can notice that the highest accuracy $(97 \%)$ was obtained for the ALI image ( 6 bands), the lowest (57\%) for the Spot image ( 3 bands). Aster image ( 3 bands) and Landsat image ( 4 bands) were classified with an overall accuracy of $83 \%$ and $64 \%$, respectively.

Table 2. Accuracy of SAM classification for images with the complete range of bands in VNIR range

\begin{tabular}{|c|c|c|c|c|}
\hline \multirow{2}{*}{ Classification accuracy } & \multicolumn{4}{|c||}{ Image (number of bands in VNIR range) } \\
\cline { 2 - 5 } & ALI (6) & LAN (4) & SPOT (3) & ASTER (3) \\
\hline \hline OA [\%] & 92.7 & 64.1 & 57.0 & 83.0 \\
\hline Kappa & 0.89 & 0.52 & 0.45 & 0.75 \\
\hline
\end{tabular}


The classification accuracy of ALI images, after eliminating single bands 1', 1, 2 was 90, 92, and 91\%, respectively (Tab. 3, Fig. 2). The mean value of accuracy with the elimination of the mentioned bands was $91 \%$. The change can be observed in the situation when band 3 (red) was eliminated from the calculations. The absence of this band caused a significant decrease in the classification accuracy, which in this case was $82 \%$ (Tab. 3). Where the first of the infrared bands in the ALI image were removed (band no. 4), classification accuracy was 88\% (Tab. 3). After the removal of the second infrared band (band no. $4^{\prime}$ ) the accuracy of $77 \%$ was obtained. The accuracy difference was 11 percentage points (Tab. 3).

In the case of the removal of two blue bands $\left(1,1^{\prime}\right)$ from the ALI image, the classification accuracy was $76 \%$ (Tab. 3), that is almost the same as the obtained for the image after the elimination of the infrared band $\left(4^{\prime}\right)$. Overall, the removal of the blue and infrared bands caused a large decrease in the values of classification accuracy.

Table 3. The classification accuracy for simulated ALI image after the elimination of subsequent bands or sets of bands

\begin{tabular}{||c|c||}
\hline Eliminated bands & OA [\%] \\
\hline \hline $1^{\prime}$ & 90.1 \\
\hline 1 & 92.1 \\
\hline $1,1^{\prime}$ & 75.8 \\
\hline 2 & 91.5 \\
\hline 3 & 81.7 \\
\hline 4 & 88.1 \\
\hline $4^{\prime}$ & 76.6 \\
\hline $1^{\prime}, 4$ & 84.5 \\
\hline 1,4 & 88.5 \\
\hline $1,1^{\prime}, 4$ & 68.7 \\
\hline $1^{\prime}, 4^{\prime}$ & 70.2 \\
\hline $1,4^{\prime}$ & 76.9 \\
\hline $1,1^{\prime} 4^{\prime}$ & 62.8 \\
\hline $4,4^{\prime}$ & 34.8 \\
\hline
\end{tabular}

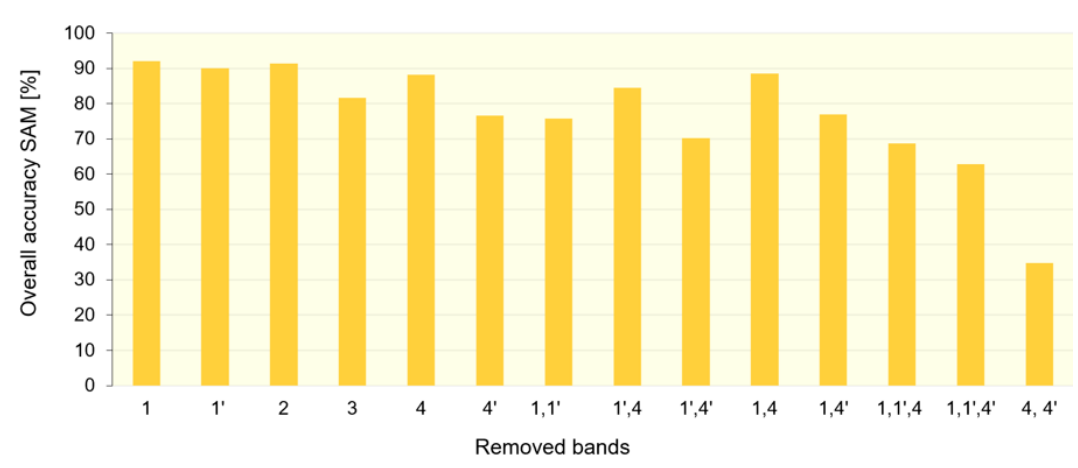

Fig. 2. The dependence of the classification accuracy SAM on the elimination of bands from the ALI image 
In the situation when both the blue band $\left(1^{\prime}\right)$ and infrared band (4) were removed, the accuracy was $85 \%$. After eliminating band $1^{\prime}$ and band $4^{\prime}, 70 \%$ accuracy was obtained (Tab. 3). In case of the removal of the blue band (1) and infrared bands (4 and $4^{\prime}$ ) the obtained accuracies were: $88 \%$ and $77 \%$, respectively (Tab. 3 ). The lowest classification accuracy $(35 \%)$ was obtained when both infrared bands (4 and $4^{\prime}$ ) were eliminated (Tab. 3). In the case of the elimination of sets consisting of 3 bands: 1, 1', 4 and 1, 1', 4, classification accuracies also significantly decreased, reaching $69 \%$ and $63 \%$, respectively (Tab. 3 ).

Values of overall accuracy obtained in SAM classification made for images ALI after the elimination of band sets: $1^{\prime}, 4^{\prime}$ and $1,1^{\prime}, 4^{\prime}$, are presented in Tables 4 and 5, respectively. Reduced ALI images had channel configurations comparable to the configuration images from Landsat, Aster and Spot (in VNIR). Table 5 also contains the values of the classification accuracy calculated for the Landsat image with the blue channel (Landsat) eliminated and the accuracy of simulated images from Aster and Spot. In this way, a table comparing the accuracy with the set of 3 bands: green, red and infrared was made (Tab. 5).

Table 4. The accuracy of SAM classification for the Landsat image from bands of VNIR and for the reduced ALI image from bands characteristic for Landsat (range VNIR)

\begin{tabular}{|c|c|c|}
\hline \multirow{4}{*}{ Classification accuracy } & \multicolumn{2}{|c|}{ Sensor (number of bands) } \\
\hline & ALI (4) & LAN (4) \\
\hline & \multicolumn{2}{|c|}{ Eliminated bands } \\
\hline & $1^{\prime}, 4^{\prime}$ & - \\
\hline OA [\%] & 70.2 & 64.1 \\
\hline Kappa & 0.61 & 0.52 \\
\hline
\end{tabular}

Table 5. The accuracy of SAM classification for images of green, red and infrared bands ( 3 bands)

\begin{tabular}{|c|c|c|c|c||}
\hline \multirow{3}{*}{ Classification accuracy } & \multicolumn{4}{|c|}{ Sensor (number of bands) } \\
\cline { 2 - 5 } & ALI (3) & \multicolumn{4}{|c||}{ LAN (3) } & SPOT (3) & ASTER (3) \\
\cline { 2 - 5 } & \multicolumn{4}{|c||}{ Eliminated bands } \\
\cline { 2 - 5 } & $1,1^{\prime}, 4^{\prime}$ & 1 & - & - \\
\hline \hline OA [\%] & 62.8 & 33.5 & 57.0 & 0.45 \\
\hline Kappa & 0.52 & 0.26 & 0.75 \\
\hline
\end{tabular}

In the case of the configuration of the ALI image, which simulated Landsat (eliminated bands $\left.1^{\prime}, 4^{\prime}\right)$ (Tab. 4) the obtained value of classification accuracy was $70 \%$, or 6 percentage points higher than the accuracy obtained for Landsat (64\%). The classification accuracy for reduced ALI images in the configuration of bands characteristic for sensors Landsat, Spot, Aster in VNIR, were significantly different than the classification accuracy obtained for these images (Tab. 5). The obtained accuracy values ranged between 33\% (Landsat) and 83\% (Aster). For the ALI image, the overall accuracy was 63\%, while for simulated Spot it was 57\%, and for Aster $83 \%$. 


\section{Discussion}

In the infrared spectral range, water fully absorbs electromagnetic radiation. If spectral reflection is recorded in this range, it is connected with the influence of the atmosphere or must originate from the particles and matter suspended in water [3]. In the presented results of the tests, there is a clear trend in the decrease in the classification accuracy of the ALI image when infrared channels are removed - from $76 \%$ when only one channel $4^{\prime}$ is removed to $35 \%$ after eliminating both infrared bands 4 and $4^{\prime}$. The difference between these accuracies is significant and equals 41 percentage points (Tab. 3). Referring to the results of the studies carried out on the original ALI data (the image recorded with the Hyperion image analyzed in this paper) [4], it should be stated that such an immense impact on the classification results of the waters in the Dobczyce Reservoir 4 is caused by the spectral properties of water. The authors of the mentioned above results show that among the applied indexes of color compositions, OIF (Optimum Index Factor) and MOIK factor, the best data set for the analysis of the waters in the reservoir are the following bands: blue (1, 1'), red (3) and infrared $\left(4,4^{\prime}\right)$. However, they emphasize that the infrared bands were put in this set because of the recording of disturbance such as smoke/fog. In the presented tests and analyses, the applied image was processed through adequate atmospheric correction based on the curves measured in situ, and without atmospheric disturbance. Therefore, one should assume that the infrared bands recorded for images Hyperion and ALI contain spectral information connected with the spectral properties of water characteristic of this reservoir.

Surprisingly high classification accuracy compared to the accuracy of the other images was obtained for Aster (83\%) (Tab. 5). The difference was as great as 20 percentage points compared to the accuracy for ALI. It should be emphasized that there was no difference in the number of bands between the reduced ALI image and the Aster image. In both images, 3 bands were used for the calculations. The analysis of spectral resolution of subsequent bands (Fig. 3) indicated that the green and red band had identical spectral characteristics of $80 \mathrm{~nm}$ and $60 \mathrm{~nm}$, respectively. Differences occurred only in the spectral resolution of the infrared band - ALI (30 nm), Aster $(80 \mathrm{~nm})$. Thus, this great decrease in classification accuracy for ALI is connected with the difference in the spectral band, where electromagnetic infrared radiation is registered. It should also be emphasized that in this configuration ALI contains only 1 infrared band (band 4). Thus, spectral information in the infrared band was significantly reduced, which resulted in the decrease of classification accuracy. Even greater difference in accuracy (50 percentage points) for images with 3 channels (green, red, infrared) was observed for the reduced image of Landsat compared to the accuracy of the Aster image (Fig. 3). In this case, the cause of such a big decrease in accuracy was the resolution of the infrared band in the Landsat image $(140 \mathrm{~nm})$. 


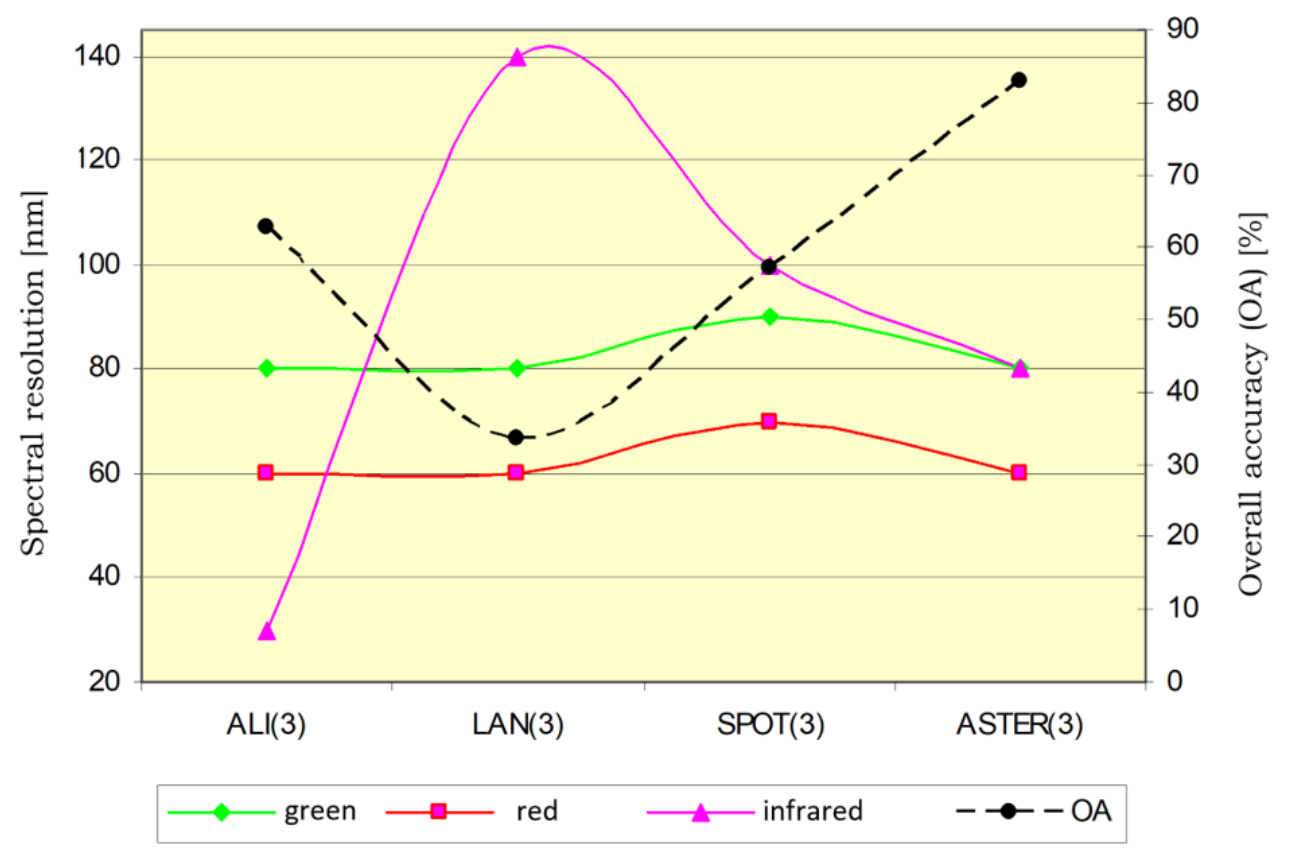

Fig. 3. Spectral resolution in VNIR for sensors: ALI, Landsat, Spot, Aster and overall accuracy $(\mathrm{OA})$ obtained for SAM classification

\section{Summary}

The analysis of the spectral information of additional spectral bands of the ALI sensor in the range of blue $\left(1,1^{\prime}\right)$ and infrared $\left(4,4^{\prime}\right)$ confirmed its great impact on the accuracy of water classification. The blue and green ranges of electromagnetic radiation are also recorded by multispectral sensors Aster, Landsat and Spot. However, it is only in single bands of poorer spectral resolution. Infrared channels of the ALI sensor have a better spectral resolution of $30 \mathrm{~nm}$ and $45 \mathrm{~nm}$, in the relation to $80-140 \mathrm{~nm}$ for the remaining analyzed multispectral sensors. Wider ranges can confirm disturbances connected with absorption by the atmosphere (mainly particles of $\mathrm{H}_{2} \mathrm{O}$ ), causing the disturbance in the recorded energy of electromagnetic radiation. Based on the simulation and reduction of bands conducted, one can state that the classification accuracy, apart from the number of channels, is very much influenced by spectral resolution. It is clearly visible in blue and infrared ranges. It turns out that in case of water, the lack of a spectral answer in the range of the infrared in the ALI image, can reduce the classification accuracy to as much as $60 \%$. The lack of the blue bands in the dataset can decrease classification accuracy of water by about $15 \%$. 


\section{References}

[1] Brando V., Dekker A.: Satellite hyperspectral remote sensing for estimating estuarine and coastal water quality. IEEE Transactions on Geoscience and Remote Sensing, vol. 41, no. 6, 2003, pp. 1378-1387.

[2] Hejmanowska B., Drzewiecki W., Głowienka E., Mularz S., Zagajewski B., Sanecki J.: Próba integracji satelitarnych obrazów hiperspektralnych z nieobrazowymi naziemnymi danymi spektrometrycznymi na przykładzie Zbiornika Dobczyckiego. Archiwum Fotogrametrii, Kartografii i Teledetekcji, vol. 16, 2006, pp. 207-216.

[3] Koponen S., Pulliainen J., Kallio K., Hallikainen M.: Lake water quality classification with airborne hyperspectral spectrometer and simulated MERIS data. Remote Sensing Environment, vol. 79, 2002, pp. 51-59.

[4] Mularz S., Drzewiecki W., Hejmanowska B., Pirowski T.: Wykorzystanie teledetekcji satelitarnej do badania procesu akumulacji zanieczyszczeń w rejonie Zbiornika Dobczyckiego. Archiwum Fotogrametrii, Kartografii i Teledetekcji, vol. 16, 2006, pp. 425-435.

[5] Rundquist D., Han L., Schalles J., Peake J.: Remote measurement of algal chlorophyll in surface waters: the case for the first derivative of reflectance near $690 \mathrm{~nm}$. Photogrammetric Engineering and Remote Sensing, vol. 62, 1996, pp. 195-200.

[6] Schalles J., Yacobi Y.: Remote detection and seasonal patterns of phycocynin, carotenoid and chlorophyll pigments in eutrophic waters. Archive for HydrobiologieSpecial Issues Advancements in Limnology, vol. 55, 2000, pp. 153-168.

[7] Gitelson A.: The peak near $700 \mathrm{~nm}$ on radiance spectra of algae and water: relationships of its magnitude and position with chlorophyll concentration. International Journal of Remote Sensing, vol. 13, 1992, pp. 3367-3373.

[8] Kavzoglu T.: Simulating Landsat ETM imagery using DAIS 7915 hyperspectral scanner data. International Journal of Remote Sensing, vol. 25, no. 22, 2004, pp. 5049-5067.

[9] Barry P., Mendenhall J., Jarecke P., Folkman M., Pearlman J., Markham B.: EO-1 Hyperion hyperspectral aggregation and comparison with EO-1 Advanced Land Imager and Landsat 7 ETM+. Geoscience and Remote Sensing Symposium, IEEE International, vol. 3, 2002, pp. 1648-1651.

[10] Börner M., Wiest L., Keller P., Reulke R., Richter R., Schläpfer D., Schaepman M.: SENSOR: a tool for the simulation of hyperspectral remote sensing systems. ISPRS Journal of Photogrammetry and Remote Sensing, vol. 55, no. 6, 2001, pp. 299-312.

[11] Goetz A., Kindel B., Ferri M., Qu Z.: HATCH: Results from Simulated Radiances, AVIRIS and Hyperion. IEEE Transactions on Geoscience and Remote Sensing, vol. 41, no. 6, 2003, pp. 1215-1222. 
[12] Jarecke P., Barry P., Pearlman J., Markham B.: Aggregation of Hyperion hyperspectral spectral bands into Landsat 7 ETM+ spectral bands. [in:] IGARSS 2001. Scanning the Present and Resolving the Future. Proceedings. IEEE 2001 International Geoscience and Remote Sensing Symposium (Cat. No.01CH37217), Sydney, NSW, Australia, 2001, vol. 6, pp. 2822-2824.

[13] Kruse F., Perry S.: Regional Mineral Mapping by Extending Hyperspectral Signatures Using Multispectral Data. [in:] 2007 IEEE Aerospace Conference, 2004.

[14] Jacquemoud S., Bacour C., Poilvé H., Frangi J.: Comparison of Four Radiative Transfer Models to Simulate Plant Canopies Reflectance: Direct and Inverse Mode. Remote Sensing of Environment, vol. 74, 2000, pp. 471-481.

[15] Schläpfer D., Böerner A., Schaepman M.: The potential of spectral resampling techniques for the simulation of APEX imagery based on AVIRIS data. [in:] Summaries of the Eighth Annual JPL Airborne Earth Science Workshop, February 9-11, 1999, 1999, pp. 377-384.

[16] Steven D., Malthus T., Baret F., Xud H., Chopping M.: Intercalibration of vegetation indices from different sensor systems. Remote Sensing of Environment, vol. 88, 2003, pp. 412-422.

[17] Milton E., Choi K.: Estimating the spectral response function of the CASI-2. [in:] RSPSoc2004: Mapping and Resources Management (Annual Conference of the Remote Sensing and Photogrammetry Society, Aberdeen, Scotland, 7-10 Sep 2004), Remote Sensing and Photogrammetry Society, 2004, pp. 1-15.

[18] Earth Observing 1 (EO-1), U.S. Geological Survey, https://archive.usgs.gov/ archive/sites/eo1.usgs.gov/hyperion.html [access: 2.10.2019].

[19] Głowienka E.: Przetwarzanie wstepne danych z hiperspektralnego sensora satelitarnego Hyperion. Archiwum Fotogrametrii, Kartografii i Teledetekcji, vol. 18, 2008, pp. 131-140.

[20] Głowienka E.: Analiza porównawcza metod przetwarzania danych hiperspektralnych o zróżnicowanej dokładności. AGH 2014 [PhD thesis, unpublished].

\section{Analiza wpływu charakterystyki spektralnej symulowanych obrazów multispektralnych na dokładność klasyfikacji wody}

Streszczenie: Teledetekcja jest szeroko wykorzystywana w badaniu parametrów stanu oraz jakości wody. Charakterystyka spektralna wody jest ściśle związana z rozpraszaniem promieniowania elektromagnetycznego przez materię zawieszoną oraz absorpcją promieniowania przez wodę i chlorofil a i b.

Multispektralny sensor ALI wyposażony jest w kanały w zakresach promieniowania elektromagnetycznego niebieskiego i czerwonego, których nie mają sensory, np. Landsat, SPOT czy Aster. Głównym celem artykułu było zbadanie, jak wpływa obecność tych kanałów na dokładność klasyfikacji wody 
przeprowadzonej na symulowanych obrazach ALI, Landsat, Spot i Aster. Symulację obrazów wykonano na podstawie hiperspektralnego obrazu z sensora Hyperion. Ze względu na właściwości spektralne wody wszystkie operacje na obrazach wykonywane były dla zakresu VNIR. Przetestowano wpływ na wyniki klasyfikacji usuwania pojedynczych kanałów lub zestawów kanałów symulowanych obrazów. Testy wykonano dla obszaru Dobczyckiego Zbiornika Wodnego. Zaobserwowano, że brak odpowiedzi spektralnej w zakresie podczerwonym obrazu ALI może obniżyć dokładność klasyfikacji nawet o 50\%. Natomiast brak w zestawie danych do klasyfikacji kanału z zakresów niebieskiego i czerwonego powoduje obniżenie dokładności klasyfikacji wody odpowiednio $15 \%$ i $10 \%$.

\section{Słowa}

kluczowe: $\quad$ symulacja spektralna, ALI, Spectral Angle Mapper (SAM), obrazy hiperspektralne, obrazy multispektralne 